\title{
Trend analysis of rainfall using Mann-Kendall, Sen's slope, moving average and least square techniques for Ahmednagar district of Maharashtra
}

\author{
Virendra N. Barai* and Rohini M. Kalunge \\ Department of Soil and Water Conservation Engineering, Mahatma Phule Krishi Vidyapeeth, \\ Rahuri, Ahmednagar (M.S.) India \\ (Email:vnbarai@gmail.com)
}

\begin{abstract}
The long-term behaviour of rainfall is necessary to study over space with different time series viz., annual, monthly and weekly as it is one of the most significant climatic variables. Rainfall trend is an important tool which assesses the impact of climate change and provides direction to cope up with its adverse effects on the agriculture. Several studies have been performed to establish the pattern of rainfall over various time periods for different areas that can be used for better agricultural planning, water supply management, etc. Consequently, the present report, entitled "Trend analysis of rainfall in Ahmednagar district of Maharashtra," was carried out. 13 tahsils of the district of Ahmednagar were selected to carry out trend analysis. The daily rainfall data of 33 years (1980 - 2012) of all stations has been processed out study the rainfall variability. The Mann Kendall (MK) Test, Sen's slope method, moving average method and least square method were used for analysis. The statistical analysis of whole reference time series data highlighted that July and August month contributes highest amount of rainfall at all tahsils. Regarding trend in annual rainfall, these four methods showed increasing trend at most of the tahsils whereas a decreasing trend only at Shrigonda tahsil. For monthly trend analysis, Kopargaon, Newasa, Shevgaon and Shrirampur tahsils showed an increasing trend during July. During August and September month, most of the tahsils i.e. Kopargaon, Nagar, Parner and Sangamner showed increasing trends, whereas in June, only Shrigonda tahsil showed decreasing trend.
\end{abstract}

Key Words : Rainfall, Mann-Kendall, Sen's Slope, Moving average, Least square, trend

View Point Article : Barai, Virendra N. and Kalunge, Rohini M. (2021). Trend analysis of rainfall using Mann-Kendall, Sen's slope, moving average and least square techniques for Ahmednagar district of Maharashtra. Internat. J. agric. Sci., 17 (1) : 19-25, DOI:10.15740/HAS/ IJAS/17.1/19-25. Copyright@2021: Hind Agri-Horticultural Society.

Article History : Received : 12.10.2020; Revised : 06.11.2020; Accepted : 08.12.2020

\footnotetext{
* Author for correspondence :
} 